\title{
Measuring Systems for Thermometer Calibration in Low-Temperature Range
}

\author{
A. Szmyrka-Grzebyk • L. Lipiński • \\ H. Manuszkiewicz • A. Kowal • A. Grykałowska • \\ D. Jancewicz
}

Received: 17 June 2010 / Accepted: 14 July 2011 / Published online: 27 July 2011

(C) The Author(s) 2011. This article is published with open access at Springerlink.com

\begin{abstract}
The national temperature standard for the low-temperature range between 13.8033 K and 273.16 K has been established in Poland at the Institute of Low Temperature and Structure Research (INTiBS). The standard consists of sealed cells for realization of six fixed points of the International Temperature Scale of 1990 (ITS-90) in the low-temperature range, an adiabatic cryostat and Isotech water and mercury triple-point baths, capsule standard resistance thermometers (CSPRT), and AC and DC bridges with standard resistors for thermometers resistance measurements. INTiBS calibrates CSPRTs at the low-temperature fixed points with uncertainties less than $1 \mathrm{mK}$. In lower temperature range-between $2.5 \mathrm{~K}$ and about $25 \mathrm{~K}$ - rhodiumiron $(\mathrm{RhFe})$ resistance thermometers are calibrated by comparison with a standard which participated in the EURAMET.T-K1.1 comparison. INTiBS offers a calibration service for industrial platinum resistance thermometers and for digital thermometers between $77 \mathrm{~K}$ and $273 \mathrm{~K}$. These types of thermometers may be calibrated at INTiBS also in a higher temperature range up to $550^{\circ} \mathrm{C}$. The Laboratory of Temperature Standard at INTiBS acquired an accreditation from the Polish Centre for Accreditation. A management system according to EN ISO/IEC 17025:2005 was established at the Laboratory and presented on EURAMET QSM Forum.
\end{abstract}

Keywords Calibration - Temperature scale $\cdot$ Thermometry

\section{Introduction}

Temperature values on the International Temperature Scale of 1990 (ITS-90) [1] in a very wide temperature range from $13 \mathrm{~K}\left(-260^{\circ} \mathrm{C}\right)$ up to about $960^{\circ} \mathrm{C}$ are defined

\footnotetext{
A. Szmyrka-Grzebyk ( ()$\cdot$ · L. Lipiński · H. Manuszkiewicz · A. Kowal · A. Grykałowska · D. Jancewicz Institute of Low Temperature and Structure Research, Okólna str. 2, 50-950 Wrocław, Poland e-mail: A.Szmyrka@int.pan.wroc.pl
} 
by means of standard platinum resistance thermometers (SPRT) calibrated at several fixed points. In practice, no single platinum thermometer can be used over the complete temperature range as an interpolating instrument. Three platinum sensors of different construction are recommended [2]; in the low-temperature part of the scale-between the triple point of hydrogen $(13.8033 \mathrm{~K})$ and the triple point of water $(273.16 \mathrm{~K})$ - a small size, "capsule type" $25 \Omega$ standard platinum thermometer (CSPRT) is used. From the triple point of argon $(83.8058 \mathrm{~K})$ to the freezing point of aluminum $\left(660.323^{\circ} \mathrm{C}\right)-\mathrm{a}$ "long-stem" $25 \Omega$ SPRT is the interpolating thermometer, whereas at the highest temperatures, from $0{ }^{\circ} \mathrm{C}$ to $961.78^{\circ} \mathrm{C}$, the $0.25 \Omega$ long-stem SPRT (named HSPRT) is the standard.

In Poland, the national temperature standard for realization of ITS-90 (by means of long-stem platinum thermometers) in the temperature range from $-189.3442{ }^{\circ} \mathrm{C}$ $(83.8058 \mathrm{~K})$ to $961.78^{\circ} \mathrm{C}$ is maintained by a national metrological institution- the Central Office of Measures (GUM) in Warsaw. The temperature standard for the lowtemperature range, which requires easy access to liquid nitrogen and helium and an experience in cryogenics, has been established at the Institute of Low Temperature and Structure Research (INTiBS) in Wrocław. In 2001 the standard was recognized by the President of GUM as the national standard for the low-temperature range from $13.8033 \mathrm{~K}$ up to $273.16 \mathrm{~K}$ [3].

INTiBS is also equipped with a cryogenics apparatus to calibrate RhFe resistance thermometers at temperatures between $2.5 \mathrm{~K}$ and about $25 \mathrm{~K}$ and different type lowtemperature thermometers above $77 \mathrm{~K}$. Two Hart/Fluke baths and an Isotech dry block calibrator are used for calibration of industrial platinum resistance thermometers, digital and liquid thermometers from $-80^{\circ} \mathrm{C}$ to $550{ }^{\circ} \mathrm{C}$.

\section{Polish National Temperature Standard for Low-Temperature Range}

ITS-90 in the low-temperature range (where capsule thermometer CSPRT is used) is defined by the resistance platinum thermometers calibrated at the following fixed points: triple point of hydrogen $(13.8033 \mathrm{~K})$, neon $(24.5561 \mathrm{~K})$, oxygen $(54.3584 \mathrm{~K})$, $\operatorname{argon}(83.8058 \mathrm{~K})$, mercury $(234.3156 \mathrm{~K})$, and the triple point of water $(273.16 \mathrm{~K})$. When CSRPT is calibrated at all triple points and at two additional temperatures close to $17.0 \mathrm{~K}$ and $20.3 \mathrm{~K}$ (determined by means of a gas thermometer or hydrogen vapor pressure-temperature relation) the scale is realized in the whole range, whereas the thermometer being calibrated here at the six triple points only, ITS-90, by definition, is realized between $24 \mathrm{~K}$ and $273 \mathrm{~K}$.

The temperature standard at INTiBS is composed of: cells for realization of six triple points of ITS-90, three CSPRTs, AC and DC resistance bridges with standard resistors, and an adiabatic cryostat.

\subsection{Thermometric Cells}

Four water triple-point cells are at the disposal of INTiBS. In order to create the direct reference to the CCT-K7 key comparison [4] for INTiBS, two water cellsIsotech No. 465 (with known isotopic composition) and UME 51-participated in 
the bilateral comparison at INRIM in Turin (EURAMET Project No. 895) [5,6]. The protocols of CCT-K7 [7] and EUROMET.T-K7 [8] for comparison of water cells were followed during the bilateral comparison. A total standard uncertainty for the realization of the water triple point at INTiBS was equal to $62 \mu \mathrm{K}$ (for $k=1$ ). The average difference between the Isotech cell and the INRIM water standard cells was $131 \mu \mathrm{K}$, with a standard deviation of the mean of $9.8 \mu \mathrm{K}$. The mean value for the difference between the UME cell and the Italian standard is $-119.0 \mu \mathrm{K}$, with a standard deviation of $49.5 \mu \mathrm{K}$. Because these differences were larger than $100 \mu \mathrm{K}$ (an acceptable value for national standard water cells) from the Key Comparison Reference Value (KCRV) obtained during the EURAMET.T-K7 comparison (EURAMET Project No. 899 [9]), INTiBS has replaced the water cell No. 465 for a new one-Isotech No. 899. The water cell presently participates in a bilateral comparison carried out at NMi Van Swinden Laboratorium (EURAMET Project No. 1163).

The mercury triple point is realized in the Isotech $\mathrm{Hg} 220$ cell. Parameters of the cell were compared to the PTB mercury cell No. M090 under EUROMET Project No. 916 [10]. The temperature difference of the triple point of mercury in the PTB and INTiBS mercury cells was equal to $0.17 \mathrm{mK}$ with an uncertainty of $0.06 \mathrm{mK}$ for $k=1$, while the standard uncertainty for the realization of the mercury triple point at INTiBS was equal to $0.18 \mathrm{mK}$ (for $k=1$ ). Mercury melting and freezing curves determined for the Isotech $\mathrm{Hg} 220$ cell at INTiBS are presented in Fig. 1.

In the years 2000 to 2003, INTiBS participated in the EU Project MULTICELLS on a new generation of sealed cells for realization of gaseous fixed points [11-14]. A model of the multicompartment cell manufactured by IMGC (presently INRIM), shown in Fig. 2, is a part of the national standard. This is the same type of multicell which was used by the Dutch NMI [15]. The multicell consists of four sealed cylindrical elements — hydrogen (E2H2), neon (E3Ne), oxygen (Eb2O2), and argon (E5Ar), filled with high-purity (never less than $99.995 \%$ ) gases under a high pressure of about 200 bar at room temperature. Basic parameters of these elements such as the latent heat of fusion, total enthalpy, and the temperature width $\Delta T$ of a phase transition determined as a difference:

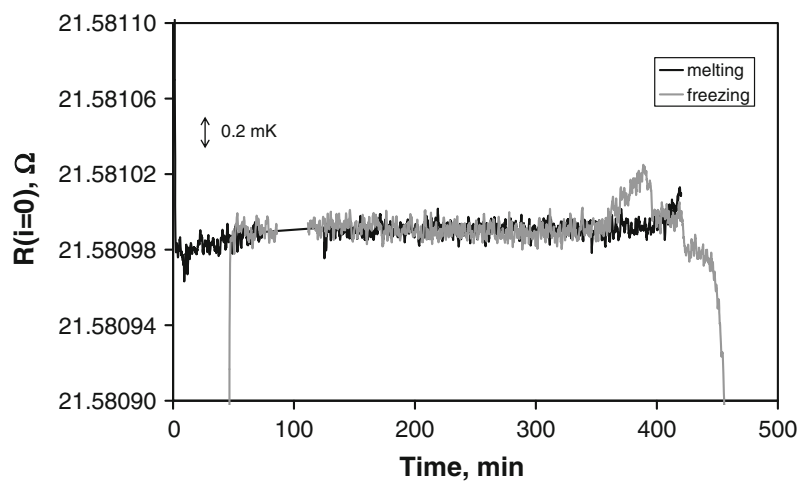

Fig. 1 Melting and freezing curves of mercury in Isotech $\mathrm{Hg} 220$ cell determined at INTiBS 


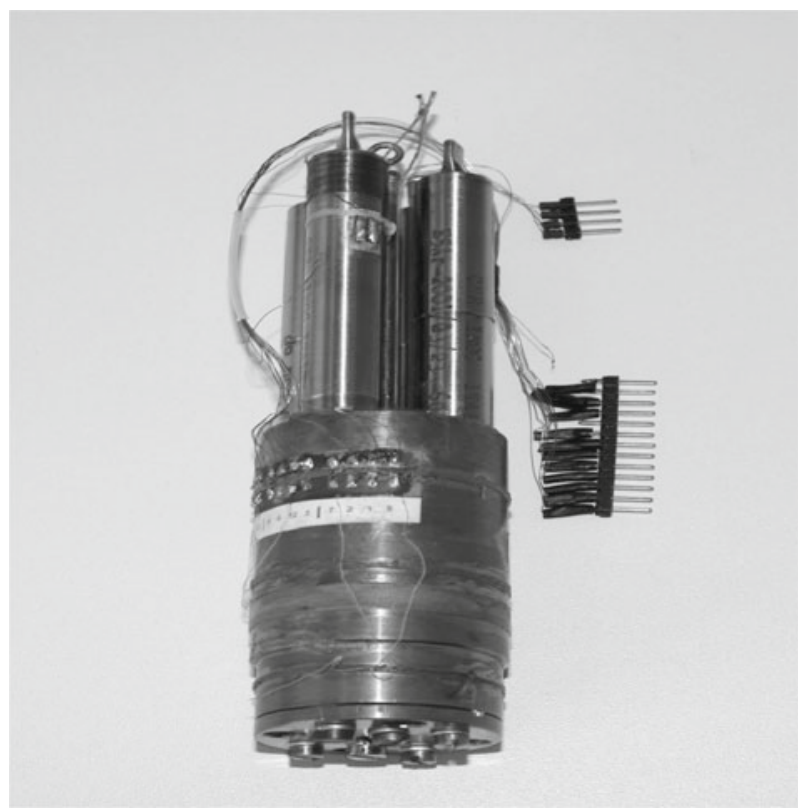

Fig. 2 IMGC model of multicompartment cell for realization of gaseous fixed points of ITS-90

$$
\Delta T=T(\text { for } F=80 \%)-T(\text { for } F=20 \%)
$$

where $F$ is the fraction of melted substance in percentage and the recovery time needed to obtain a stable condition within $30 \mu \mathrm{K}$ in cells are presented in Table 1.

For temperature measurements at argon or oxygen points, capsule platinum resistance thermometers (CSPRT) were used, whereas at lower temperatures- $\mathrm{a}$ RhFe resistance thermometer was preferred (because of its higher sensitivity).

The heat capacity was established during continuous heating of the cell with a constant power equal to about $2 \mathrm{~mW}$ in a temperature range close to a phase transition. The melting plateau of a reference substance was determined using a pulse heating method described in many papers $[2,16]$. Experimental results of argon melting for the E5Ar cell using the heat pulse method are shown in Fig. 3. After each heat pulse (and following appropriate recovery time), when the temperature was stable within several $\mu \mathrm{K}$ (typically $100 \mu \mathrm{K}$ or $30 \mu \mathrm{K}$ for the most accurate measurements), the resistance of CSPRT was measured. Melting curves presented as a function of the CSPRT resistance $R$ versus $F$ are shown in Fig. 4.

During realization of the EU Project MULTICELLS, the influence of an isotopic composition and a catalyst on the temperature of the hydrogen triple point was also investigated. At INTiBS, six cells with various quantities of catalyst $\left(\mathrm{Ga}_{2} \mathrm{O}_{3}\right)$ and different ratio D/H (from $25 \mathrm{mmol} \mathrm{D} / \mathrm{mol} \mathrm{H}$ to $185 \mathrm{mmol} \mathrm{D} / \mathrm{mol} \mathrm{H}$ ) were tested. The obtained results are presented in Fig. 5. These results were confirmed by other partners realizing the project [17-19]. 


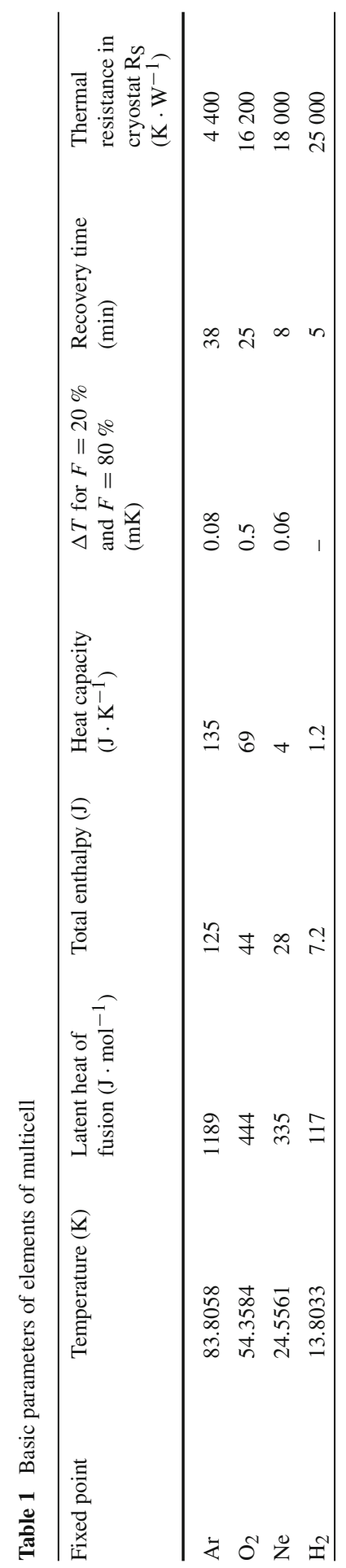




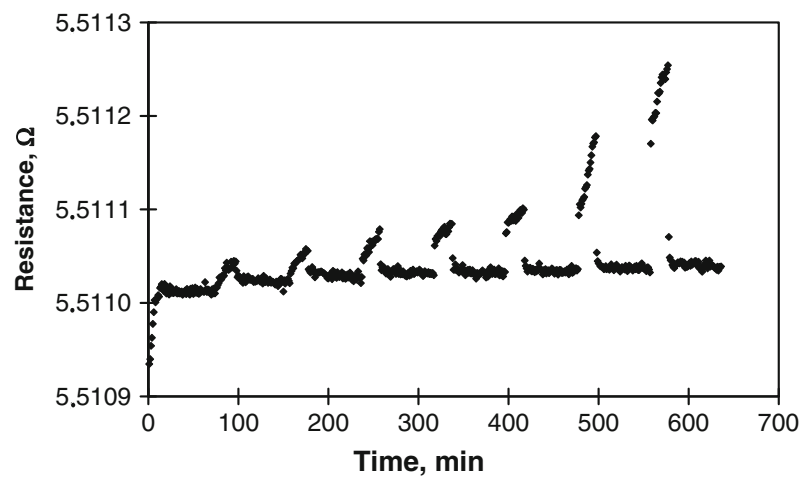

Fig. 3 Determination of melting plateau for the E5Ar cell by the heat pulse method

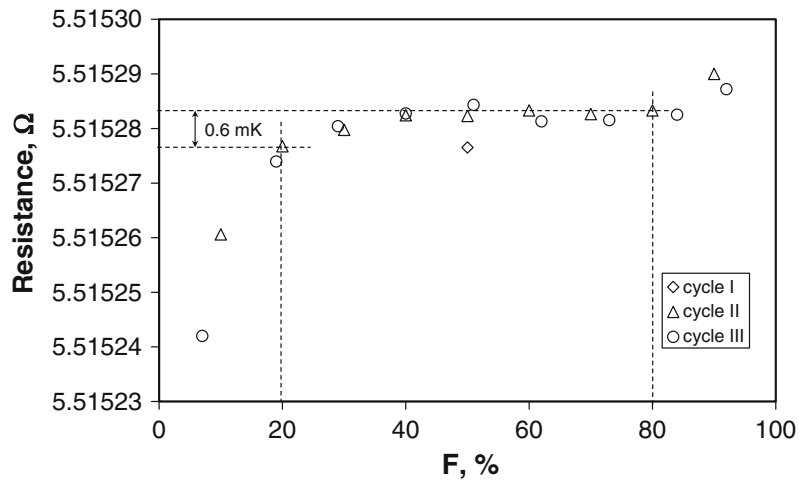

Fig. 4 Melting plateau of argon in the E5Ar cell

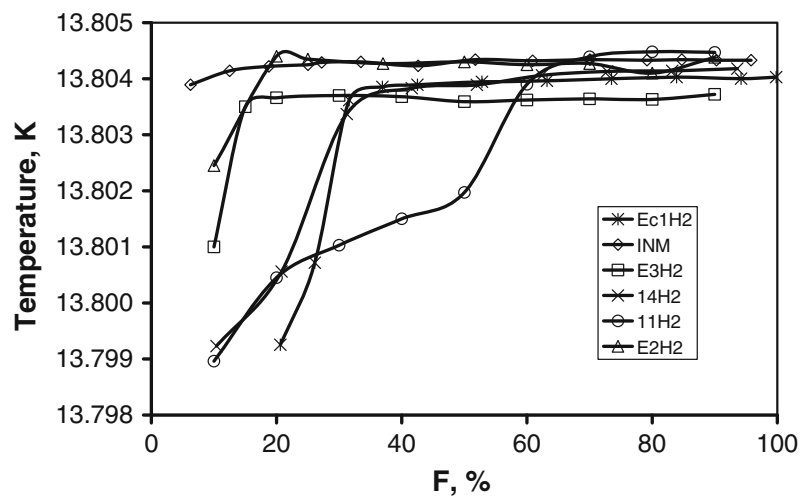

Fig. 5 Melting plateaus in cells of hydrogen with different ratios D/H and various ratios of catalyst $\left(\mathrm{Ga}_{2} \mathrm{O}_{3}\right)$ liquid volume (CLVR): $11 \mathrm{H} 2-124 \mathrm{mmol} \mathrm{D} / \mathrm{mol} \mathrm{H}$; CLVR $=0.78 .14 \mathrm{H} 2-124 \mathrm{mmol} \mathrm{D} / \mathrm{mol} \mathrm{H}$; CLVR $=$ 0.47. E2H2-155 mmol D/mol H; CLVR $=0.2$. E3H2-46 mmol D $/ \mathrm{mol} \mathrm{H} ; \mathrm{CLVR}=0.2$. Ec1H2$120 \mathrm{mmolD} / \mathrm{mol} \mathrm{H}$; CLVR $=0.5$. Cell INM was filled with $\mathrm{FeO}$ as a catalyst 
Table 2 Calibration and measurement services (CMC) offered by INTiBS presented in BIPM KCDB

\begin{tabular}{llcl}
\hline Instrument & Method & Temperature $(\mathrm{K})$ & $\begin{array}{l}\text { Expanded } \\
\text { uncertainty }(\mathrm{mK})\end{array}$ \\
\hline CSPRT & At neon triple point & 24.5561 & 0.47 \\
CSPRT & At oxygen triple point & 54.3584 & 0.43 \\
CSPRT & At argon triple point & 83.8058 & 0.34 \\
CSPRT & At neon triple point & 234.3156 & 0.38 \\
\hline
\end{tabular}

\subsection{Capsule Standard Platinum Resistance Thermometers}

Two capsule standard platinum resistance thermometers (CSPRT) being at the disposal of INTiBS-Leeds \& Northrup No. 1866334 and Tinsley No. 234721-were chosen for the international comparison. A trilateral comparison between NRC, INTiBS, and LNE-INM was carried out to provide a link of the INTiBS thermometers to the CCTK2.4 key comparison (EUROMET Project No. 733) and to determine the accuracy of the local realization of ITS-90 in the low-temperature range from $24 \mathrm{~K}$ to $273.16 \mathrm{~K}$. The comparisons have revealed calibrations at INTiBS being in agreement with the BIPM Key Comparison Reference Value (KCRV) of the CCT-K2 within the expanded uncertainty for all temperatures of the comparison, with the exception of the hydrogen triple point, based on the data for CSPRT Leeds \& Northrup No. 1866334. CSPRT Tinsley No. 234721 has been spoiled, probably during transportation. The final report of the comparison [20] was sent to CCT in September 2009.

The linkage to the CCT-K2 data supports inclusion of the INTiBS CMC (Calibration and Measurement Capabilities) in Appendix C of the Key Comparison Database KCDB [21]. In Table 2 the calibration and measurement services of INTiBS in the low-temperature range are presented.

The thermometer resistances are measured with the Measurements International 6015T resistance bridge and standard resistors calibrated at GUM. Tinsley standard resistors (Model 5685) placed in temperature-controlled enclosures were used as references: a $1 \Omega$ resistor for the measurements at the hydrogen and neon triple points and a $25 \Omega$ resistor for the oxygen, argon, mercury, and water triple points. To determine the self-heating correction (and the resistance value extrapolated at zero current, $R_{I=0}$ ), three measuring currents were used: $I_{1}=\sqrt{ } 2 \mathrm{~mA}, I_{2}=2 \mathrm{~mA}$, and $I_{3}=2 \sqrt{ } 2 \mathrm{~mA}$.

\subsection{Cryostat}

A copper block with the four fixed-point cells (multicell) and three CSPRTs was mounted in the measuring chamber of the adiabatic cryostat, surrounded by two thermal shields. The shields are made with gold-plated copper. The thickness of the copper walls is about $2 \mathrm{~mm}$. Electrical wires (50 $\mu \mathrm{m}$ copper) are anchored to two isothermal platforms (Fig. 6) for which the temperature is maintained close to the fixed-point temperature with the usage of small-size Pt and RhFe thermometers and the temperature controller Lake Shore Cryotronics (LSC) Model 340. Also, the thermal shield 


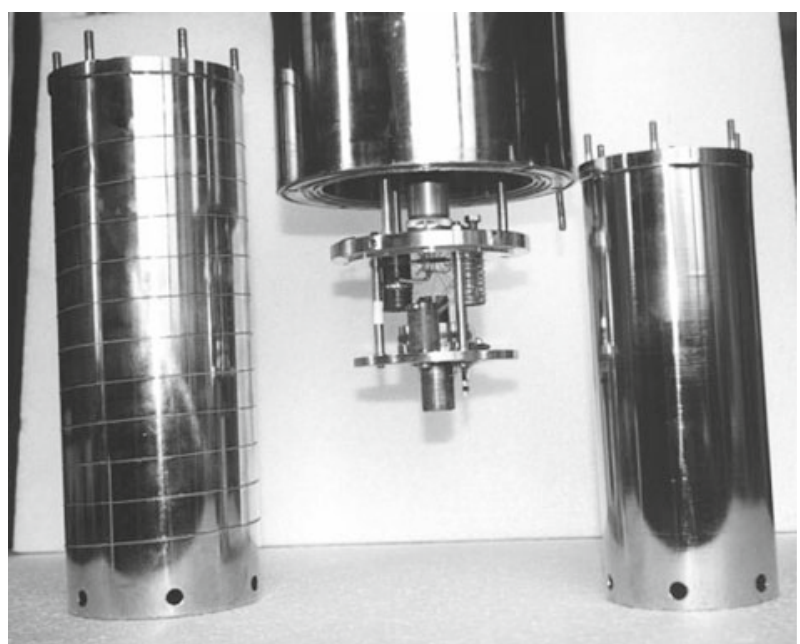

Fig. 6 Measuring chamber of the adiabatic cryostat

temperature is controlled by another LSC device-Model 370. The thermal resistance $R_{\mathrm{S}}$ of the cryostat was calculated to be about $4000 \mathrm{~K} \cdot \mathrm{W}^{-1}$ at the argon triple-point temperature and about $25000 \mathrm{~K} \cdot \mathrm{W}^{-1}$ at the hydrogen triple-point temperature [12]. In these conditions parasitic heat between the cell and adiabatic shields was less than $10 \mu \mathrm{W}$.

The measurement process has been automatically controlled by computer programs written in Visual Basic and LabView languages. These programs were written by INTiBS employees.

\section{System for Calibration of RhFe Thermometers}

In the low temperature range, between $2.5 \mathrm{~K}$ and about $25 \mathrm{~K}$, secondary standardsthe rhodium-iron (RhFe) resistance thermometers are used at INTiBS. One of themTinsley-Type 5187W No. B 178 calibrated at the National Physical Laboratory (NPL) against ITS-90 between $0.65 \mathrm{~K}$ to $27.1 \mathrm{~K}$ presently participates in the comparison EURAMET.T-K1.1 (EURAMET Project No. 1147). The resistance of the thermometer was checked several times at the triple points of neon and hydrogen and the lambda point of liquid helium $(2.1768 \mathrm{~K})$. Reproducibility of the thermometer at the above mentioned fixed points is better than $0.1 \mathrm{mK}$.

INTiBS is equipped with a home-made cryostat which is used for RhFe thermometer calibration by comparison with the standard one. Eight RhFe thermometers can be mounted in a cylindrical copper block shown in Fig. 7. Recently, new types of Chinese $\mathrm{RhFe}$ thermometers were tested [22,23]. The resistance $(R)$ versus temperature ( $T$ ) characteristics of one of them is presented in Fig. 8. Reproducibility of the RhFe thermometers after 30 and 60 thermal cycles were measured at about $4.7 \mathrm{~K}$ (Fig. 9).

For resistance measurements the ASL F18 bridge or Hart/Fluke Superthermometer Model 1590 were used. 


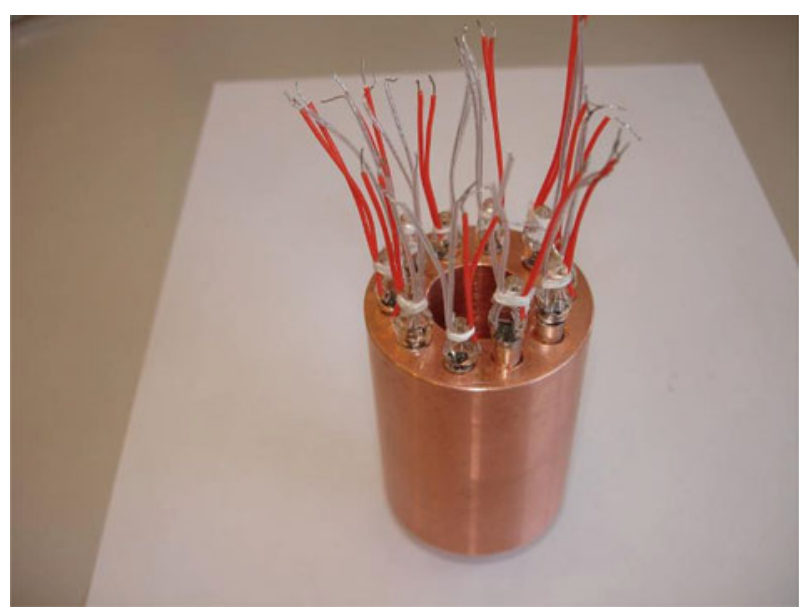

Fig. 7 RhFe thermometers in a cylindrical copper block

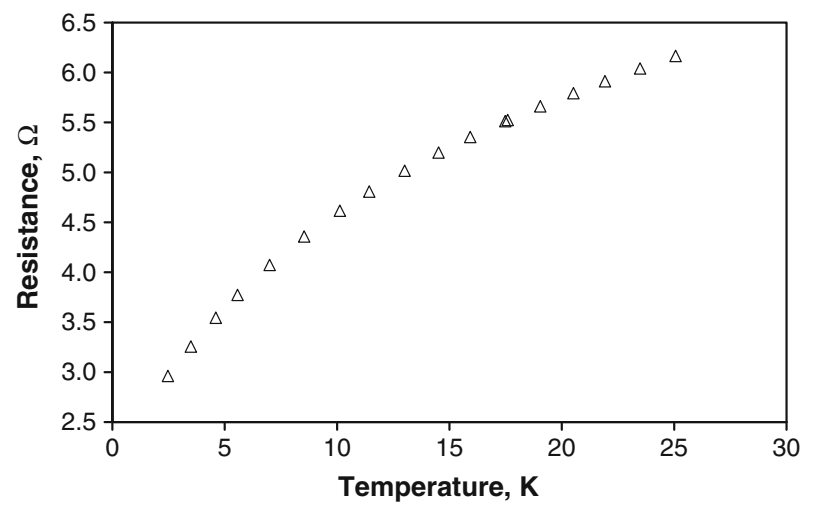

Fig. $8 R$ versus $T$ characteristics of RhFe thermometer

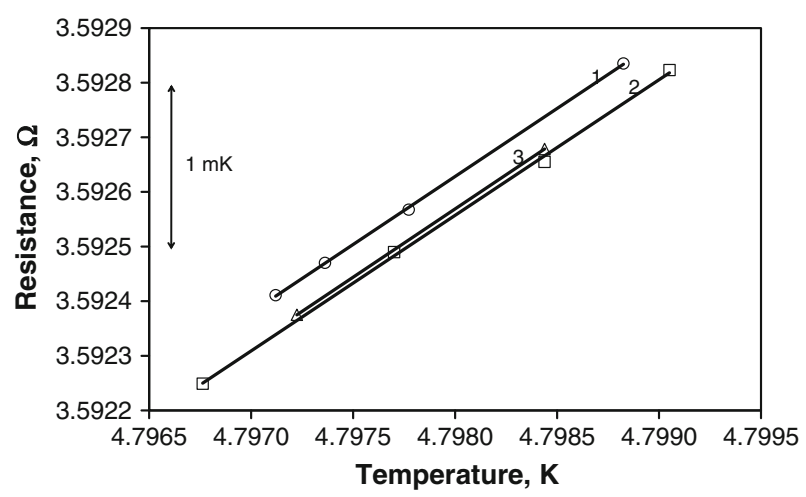

Fig. 9 Reproducibility of the Chinese RhFe thermometers after 30 and 60 thermal cycles 


\section{Calibration of Industrial Platinum Resistance Thermometers and Digital Thermometers}

INTiBS can calibrate various types of industrial platinum resistance thermometers as well as digital thermometers with Pt sensors or thermocouples in the temperature range between $77 \mathrm{~K}$ and $273 \mathrm{~K}$. These types of thermometers may be calibrated at INTiBS also in a higher temperature range up to $550{ }^{\circ} \mathrm{C}$. In the temperature range above the water triple point up to $550^{\circ} \mathrm{C}$, INTiBS calibrates them by comparison with SPRT calibrated at the Central Office of Measures (GUM).

For calibrations below $-80^{\circ} \mathrm{C}$, a home-made cryostat is used. Above $-80^{\circ} \mathrm{C}$, thermometers are calibrated in liquid baths Hart/Fluke 7380 and Hart/Fluke 7381; in the low range, Cryoil is used between $-80^{\circ} \mathrm{C}$ and $0^{\circ} \mathrm{C}$, methyl alcohol above $0{ }^{\circ} \mathrm{C}$ up to $25^{\circ} \mathrm{C}$, and distilled water in higher temperatures up to $95^{\circ} \mathrm{C}$. The expanded uncertainty of calibration (CMC) for $k=2$ in the temperature range up to $95^{\circ} \mathrm{C}$ is estimated to be $0.01{ }^{\circ} \mathrm{C}$. Above $95 \mathrm{~K}$, thermometers are calibrated in a dry block calibrator MEDUSA 3 (Isotech). Digital thermometers-Superthermometer (Hart-Fluke Model 1590) or Cropico 3000 with calibrated SPRTs are used for temperature measurements. Expanded uncertainties of calibration in the temperature range from $95^{\circ} \mathrm{C}$ to $200^{\circ} \mathrm{C}$ is equal to $0.02^{\circ} \mathrm{C}$, above $200^{\circ} \mathrm{C}$ up to $400^{\circ} \mathrm{C},-0.1^{\circ} \mathrm{C}$, and at the highest temperatures is $0.2^{\circ} \mathrm{C}$.

\section{Summary}

INTiBS is one of few laboratories where various types of thermometers can be calibrated in a wide temperature range from $2.5 \mathrm{~K}$ to $550^{\circ} \mathrm{C}$.

In the low temperature range, between $13.8033 \mathrm{~K}$ and $273.16 \mathrm{~K}$, CPRSTs can be calibrated at six fixed points.

In the range between $2.5 \mathrm{~K}$ and $25 \mathrm{~K}, \mathrm{RhFe}$ thermometers are calibrated by comparison with a high accuracy.

Various types of industrial platinum resistance thermometers as well as digital thermometers are calibrated in the temperature range between $77 \mathrm{~K}$ up to $550{ }^{\circ} \mathrm{C}$.

The service offered by INTiBS is under accreditation of the Polish Centre for Accreditation [24].

A management system according to EN ISO/IEC 17025:2005 has been implemented and maintained in the Laboratory of Temperature Standard at INTiBS. The QMS was presented on EUROMEY QS-Forum in Bucharest (2005) and Thessaloniki (2009).

Acknowledgment The work was partially realized under the project of the Ministry of Science and High Education no. KB/58/13484/IT1-B.

Open Access This article is distributed under the terms of the Creative Commons Attribution Noncommercial License which permits any noncommercial use, distribution, and reproduction in any medium, provided the original author(s) and source are credited. 


\section{References}

1. H. Preston-Thomas, Metrologia 27, 3 (1990)

2. Supplementary Information for the International Temperature Scale of 1990, Monograph (BIPM, Sèvres Cedex, France, 1997)

3. A. Szmyrka-Grzebyk, L. Lipiński, H. Manuszkiewicz, A. Kowal, in 2nd International Seminar and Workshop on Low Temperature Thermometry (Wroclaw, Poland, 2003)

4. M. Stock, S. Solve, D. del Campo, V. Chimenti, E. Méndez-Lango, H. Liedber, P.P.M Steur, P. Marcarino, R. Dematteis, E. Filipe, I. Lobo, K.H. Kang, K.S. Gam, Y.-G. Kim, E. Renaot, G. Bonnier, M. Valin, R. White, T.D. Dransfield, Y. Duan, Y. Xiaoke, G. Strouse, M. Ballico, D. Sukkar, M. Arai, A. Mans, M. de Groot, O. Kerkhof, R. Rusby, J. Gray, D. Head, K. Hill, E. Tegeler, U. Noatsch, S. Duris, H.Y. Kho, S. Ugur, A. Pokhodun, S.F. Gerasimov, Metrologia 43, Tech. Suppl. 03001 (2006)

5. M. Stock, S. Solve, Technical Protocol (BIPM, Sèvres Cedex, France, 2002)

6. A. Peruzzi, O. Kerkhof, R. Bosma, Technical Protocol for the EURAMET Comparison of Water Triple Point Cells (EURAMET.T-K7), (NMi van Swinden Laboratorium, Delft, The Netherlands, 2006)

7. P.P.M. Steur, Thermometry, EUROMET Project No. 895, Final Report (2008)

8. A. Szmyrka-Grzebyk, L. Lipiński, A. Kowal, P.P.M. Steur, R. Dematteis, Metrol. Meas. Syst. XV (2008)

9. A. Peruzzi, M. Dobre, O. Kerkhof. R. Bosma, Report to the CCT on Key Comparison EURAMET.T-K7 (NMi van Swinden Laboratorium, Delft, The Netherlands, 2008)

10. A. Szmyrka-Grzebyk, Thermometry, EUROMET Project No. 916, Final Report (2011)

11. F. Pavese, D. Ferri, I. Peroni, P.P.M. Steur, in Proceedings of TEMPMEKO 2001, 8th International Symposium on Temperature and Thermal Measurements in Industry and Science, ed. by B. Fellmuth, J. Seidel, G. Scholz (VDE Verlag, Berlin, 2002), pp. 771-776

12. F. Pavese, D. Ferri, I. Peroni, A. Pugliese, P.P.M. Steur, B. Fellmuth, D. Head, L. Lipiński, A. Peruzzi, A. Szmyrka-Grzebyk, L. Wolber, in Temperature: Its Measurement and Control in Science and Industry, vol. 7, ed. by D.C. Ripple (AIP, Melville, 2003), pp. 173-178

13. L. Lipiński, A. Szmyrka-Grzebyk, H. Manuszkiewicz, A. Kowal, in Joint IMEKO TC-1 \& XXXIV MKM Conference 2002, vol. III (Wroclaw, Poland, 2002)

14. H. Manuszkiewicz, B. Fellmuth, D. Head, Y. Hermier, L. Lipiński, F. Pavese, A. Peruzzi, A. SzmyrkaGrzebyk, L. Zanin, in Seminar TEMPERATUR 2003 (Berlin, 2003)

15. A. Peruzzi, R. Bosma, J. van den Hark, Int. J. Thermophys. 28, 1882 (2007)

16. F. Pavese, G. Molinar, Modern Gas-Based Temperature and Pressure Measurements (Plenum Press, New York/London, 1992)

17. B. Fellmuth, L. Wolber, Y. Hermier, F. Pavese, P.P.M. Steur, I. Peroni, A. Szmyrka-Grzebyk, L. Lipinski, W.L. Tew, T. Nakano, H. Sakurai, O. Tamura, D. Head, K.D. Hill, A.G. Steele, Metrologia 42, 171 (2005)

18. B. Fellmuth, Y. Hermier, F. Pavese, A. Szmyrka-Grzebyk, W. Tew, in Proceedings of TEMPMEKO 2001, 8th International Symposium on Temperature and Thermal Measurements in Industry and Science, ed. by B. Fellmuth, J. Seidel, G. Scholz (VDE Verlag, Berlin, 2002), pp. 403-410

19. F. Pavese, B. Fellmuth, D. Head, Y. Hermier, H. Sakurai, K. Hill, A. Szmyrka-Grzebyk, W.L. Tew, BIPM Document, "CCT/2003-16”, (BIPM, Sèvres Cedex, France, 2003)

20. K.D. Hill, A.G. Steele, A. Szmyrka-Grzebyk, L. Lipiński, Y. Hermier, L. Pitre, F. Sparasci, CCT-K2.4, Final Report (2009)

21. http://www.bipm/KCDB

22. F. Pavese, A. Szmyrka-Grzebyk, L. Lipiński, H. Manuszkiewicz, P. Qiu, J.T. Zhang, P. Lin, X.W. Li, Int. J. Thermophys. 29, 51 (2008)

23. L. Lipiński, A. Szmyrka-Grzebyk, P. Lin, X.W. Li, H. Manuszkiewicz, D. Jancewicz, A. Grykalowska, P.P.M. Steur, F. Pavese, Int. J. Thermophys. 31, 1696 (2010)

24. Polish Centre for Accreditation, Certificate No. AP 125 (2011) 